\title{
Editorial: The Narrative Turn
}

\author{
Patrick Lewis \\ University of Regina
}

That was all I have ever owned, stories. Indeed, our story is finally all any of us owns, because as I once told my grandson, a story has only one master. Frank Delaney, (2005)

Narrative research has grown dramatically, if not exponentially, since appearing on the qualitative research horizon more than 20 years ago. ${ }^{1}$ From Bruner $(1986,1987,1990)$ to Polkinghorne (1988), Riessman (1992), to Barone (1995), Denzin (1997), to Connelly \& Clandinin (1990, 2000) and a plethora of others, the field has been well cultivated and has yielded fine crops. The third issue of in education is dedicated to sharing some of that narrative research yield.

In the field of education, one particular form of narrative work stands out, and that is, of course, narrative inquiry as delineated by Connelly and Clandinin (1990). However, since that time, Clandinin and Connelly (2000) and Clandinin (2007) have built upon and evolved the work and many other researchers have joined them along the way, adding to and augmenting the methodology. Huber (2004), Murphy (2006), Murray-Orr (2007) and Pushor (2007), to name only a few, have contributed much to narrative inquiry. Nevertheless, narrative in the research world is a broad term that has come to, and continues to manifest itself in multiple ways across several disciplines, such as, narrative psychology, narrative sociology, and anthropology, integrating critical ethnography and life histories. Beyond specific disciplines, there is a host of researchers who engage in autoethnography, self-study, memory work, autobiography, performance narrative, and narrative dialogue to create stories from lived experiences in their research work (Ellis \& Bochner, 2000, Ellis, 2004; Bochner, 1997; Brogden, 2008; Lewis, 2006; Pelias, 2008; Spry, 2001).

Narrative imagining - story-is a deeply human activity possessed with both ontological and epistemological implications in human experience and existence. Humans have a symbiotic relationship with story in that we are both informed by story and formed by story. Consequently, with narrative understanding at the centre of meaning making, narrative research in education has a significant part to play in the pedagogical playground. Dwayne Huebner (1999/1987) suggested that the pedagogical project is a journey into story: "Human life is a journey with a narrative structure that is best expressed in story form. We tell our own story, and come to know that of others" (p. 382). Narrative is fundamental to being human and if we are mindful in our living narratively, we may, through story, discover much about human being. Such narrative discoveries do not lead to some object TRUTH about the human experience; rather, they open up a multitude of human truths that are, albeit messy, far richer and more informative in both their complexity and simplicity.

Yet, oft times there is a question of trusting the story and/or the storyteller in narrative work. This may spring from the notion that anything (story, narrative imagining) so plentiful and widely available cannot be of much value; however, its worth is in the fact that narrative understanding makes us human. Michel de Certeau (1984) noted that stories "constantly transform places into spaces or spaces into places," suggesting that stories become spaces of resistance; they resist the dominant narratives of instituted power: "Stories offer their audience a repertory of tactics for future use” (p. 23). More importantly, it is in the stories of the quotidian, 
in our trying to live well alongside the challenges and struggles of "the-every-day" that we may engender some insight or percipience. "What I would like to suggest then is that research is not ultimately about interpretation but about faith. Trusting in the stories and the storyteller" (Hendry, 2007, p. 494). Narrative imagining is possessed with the potential to actualize small discoveries; the actualization of that potential is through the "journey into story" and the story's end. Narrative researchers must hold the space for the storyteller and her story, transforming the place and the space, listening the story into being. It is through story that we may come to know and be. Story allows us to imagine the world otherwise, which enables us to act and in that action offer counter narratives to those of the instituted powers.

This issue of in education includes ten articles that cut across some of the expansive and undulating narrative research landscape. There are also two book reviews of works that fall under the aegis of narrative research. Rather than introduce each article, as is traditional in the editorial, I invite you to utilize the digital format and capabilities of the journal to explore narratively the works shared herein. 


\section{References}

Barone, T. (1995). Persuasive writings, vigilant readings, and reconstructed characters: The paradox of trust in educational story sharing. In J. A. Hatch, \& R. Wisniewski (Eds.), Life history and narrative (pp. 63-74). Washington, D.C.: The Falmer Press.

Bochner, A. (1997). It's about time: Narrative and the divided self. Qualitative Inquiry, 3, 418438.

Brogden, L. M. (2008). Art•I/f/act•ology: Curricular artifacts in autoethnographic research. Qualitative Inquiry, 14(6), 851-864.

Bruner, J. (1986). Actual minds, possible words. Cambridge, MA: Harvard University Press.

Bruner, J. (1987). Life as narrative. Social Research, 54, 11-32.

Bruner, J. (1990). Acts of meaning. Cambridge, MA: Harvard University Press.

Certeau de, M. (1984). The practice of everyday life. Los Angeles, CA: University of California Press.

Clandinin, D. J. \& Connoly, F. M. (2000). Narrative inquiry: Experience and story in qualitative research. San Francisco, CA: Jossey-Bass.

Clandinin, D. J. (2007). Handbook of narrative inquiry: Mapping a methodology. Thousand Oaks, CA: Sage.

Clandinin, D. J., Pushor, D., \& Murray-Orr, A. (2007). Navigating sites for narrative inquiry. Journal of Teacher Education, 58(1), 21-35.

Connelly, F.M., \& Clandinin, D. J. (1990). Stories of experience and narrative inquiry. Educational Researcher, 19, 2-14.

Denzin, N.K. (1997). Interpretive ethnography: Ethnographic practices for the 21st century. Thousand Oaks, CA: SAGE Publications Inc.

Ellis, C., \& Bochner, A. (2000). Autoethnography, personal narrative, reflexivity: Researcher as subject. In N. Denzin \& Y. Lincoln (Eds.), The handbook of qualitative research (2nd ed., pp. 733-768). Thousand Oaks, CA: Sage.

Ellis, C. (2004). The ethnographic I: A methodological novel about autoethnography. Walnut Creek, CA: AltaMira Press.

Hendry, P. M. (2007). The future of narrative. Qualitative Inquiry, 13(4), 487-498.

Huber, J., Murphy, M.S., \& Clandinin, D. J. (2004). Creating communities of cultural imagination: Negotiating a curriculum of diversity. In J. Phillion, M. F. He, \& F. M. Connelly (Eds.), Multicultural education: Narrative and experience. San Francisco: Sage Publishing.

Huebner, D. (1999/1987). Teaching as vocation. In V. Hillis (Ed.), The lure of the transcendent: Collected essays by Dwayne Huebner (pp. 379-387). Mahwah, NJ: Lawrence Erlbaum Associates.

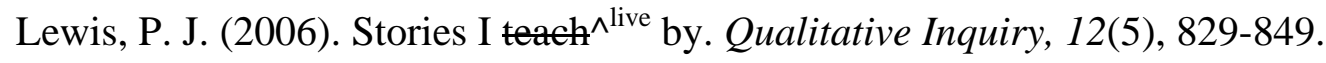


Polkinghorne, D. E. (1988). Narrative knowing and the human sciences. New York: State University of New York Press.

Riessman, C.K. (1993) Narrative analysis. Boston, MA: Boston University.

Spry, T. (2001). Performing autoethnography: An embodied methodological praxis. Qualitative Inquiry, 7(6),706-732.

\section{Endnotes}

1 Narrative work can be traced back to the 1920s and the Chicago School of anthropology, the 1960s and 1970s feminist work and the sociolinguistic work of the 1970s and early 1980s. 